\title{
Imunological and clinical characteristics in children with polyarteritis nodosa: a retrospective study over the last 20 years
}

\author{
Masa Vikic Topic ${ }^{*}$ Ivan Malcic, Danica Batinic, Danko Milosevic, Mandica Vidovic, Katarina Starcevic, Kristina Potocki, \\ Branko Malenica, Marija Jelusic-Drazic
}

From 18th Pediatric Rheumatology European Society (PReS) Congress

Bruges, Belgium. 14-18 September 2011

\section{Aim}

Analysis of polyarteritis nodosa (PAN) characteristics such as laboratory parameters, affected organs, treatment modalities and disease outcome.

\section{Methods}

Our study includes all children aged 1-18 with PAN diagnosed according to EULAR/PRES/PRINTO criteria at Department of Paediatrics, University Hospital Centre Zagreb, Croatia, during the period of 1991-2010.

\section{Results}

PAN was diagnosed in 12 patients ( 6 girls and 6 boys). The share of PAN amongst all vasculitides was $4 \%$. The mean age at disease onset was $( \pm$ SD) $11.33 \pm 3,08$ years. Systemic PAN was diagnosed in 7 children (58\%), microscopic polyangiitis in $3(25 \%)$, cutaneus PAN in 2 (17\%) and classic PAN in $0(0 \%)$. The most consistent symptoms were skin involvement (90\%) and arthritis/ arthralgia (60\%). The CNS was affected in $40 \%$ of patients. ESR and CRP were elevated in all patients. Antineutrophil cytoplasmic antibodies were elevated in 3 patients (25\%). Antistreptolysin O was elevated in 4 patients (25\%). The relation between the severity of skin involvement and involvement of other organs was not found. Therapy mode for all patients was corticosteroids. Immunosuppressive drugs and Rituximab (antiCD20) were used as additional therapy for patients with severe symptoms. Two patients with microscopic polyangiitis died due to chronic renal and pulmonary failure during the follow-up.

University Hospital Centre Zagreb, University of Zagreb School of Medicine, ZAGREB, Croatia

\section{Conclusion}

In comparison to available studies, we found a difference in distribution of childhood polyarteritis nodosa as well as some clinical characteristics (e.g. higher prevalence of neurological symptoms), while other researched features, laboratory and treatment, were similar.

Published: 14 September 2011

doi:10.1186/1546-0096-9-S1-P91

Cite this article as: Topic et al:: Imunological and clinical characteristics in children with polyarteritis nodosa: a retrospective study over the last 20 years. Pediatric Rheumatology 2011 9(Suppl 1):P91.
Submit your next manuscript to BioMed Central and take full advantage of:

- Convenient online submission

- Thorough peer review

- No space constraints or color figure charges

- Immediate publication on acceptance

- Inclusion in PubMed, CAS, Scopus and Google Scholar

- Research which is freely available for redistribution
() Biomed Central 